\title{
ShOUld DeAd Men Walk Forever? A LOOK INTO INDIANA's EXECUTION DILEMMA, THE CONSTITUTIONALITY OF INDEFINITE DEATH SENTENCES, AND WHAT COMES NEXT FOR INDIANA
}

\author{
VIRGINIA MARSO*
}

\section{INTRODUCTION}

In 1997, Joseph Corcoran was living with his brother James, his sister Kelly, and her fiancé, Robert Turner. ${ }^{1}$ One evening after Corcoran overheard James, Robert, and James' friends Timothy and Doug talking negatively about him, he became infuriated. ${ }^{2}$ He went upstairs, put his seven-year-old niece to bed, loaded his semiautomatic rifle, and proceeded to execute James, Timothy, Doug, and Robert. ${ }^{3}$ Afterwards, he laid the rifle down, went next door, and asked his neighbor to call the police. ${ }^{4}$ On August 26, 1999, the trial court sentenced Corcoran to death. ${ }^{5}$ The U.S. Court of Appeals for the Seventh Circuit heard Corcoran's case four times, ${ }^{6}$ and on his final appeal, upheld the decisions of the lower courts to execute him. ${ }^{7}$ Corcoran's case exhausted all state court remedies and even found its way to the U.S. Supreme Court twice. ${ }^{8}$ Corcoran exhausted all of his appellate remedies in 2016, and his death sentence was upheld. ${ }^{9}$

On August 18, 2019, the Indiana Department of Corrections ("IDOC") confirmed to the public that Indiana does not have the necessary drugs to perform

* Virginia (Janie) Marso, J.D., 2021, Indiana University Robert H. McKinney School of Law; B.A., 2017, Miami University - Oxford, Ohio.

1. Tim Evans, Indiana Death Row Holds 11 Prisoners, Indianapolis StaR (June 13, 2017, 11:41 AM), https://www.indystar.com/story/news/2014/01/31/indiana-death-row-holds-13prisoners/5037977/ [https://perma.cc/MB6V-L4LE].

2. $I d$.

3. $I d$.

4. Id.

5. Id

6. Corcoran v. Buss, 551 F.3d 703 (7th Cir. 2008) (prosecutor did not chill capital murder defendant's exercise of his Sixth Amendment right to jury trial); Corcoran v. Levenhagen, 593 F.3d 547 (7th Cir. 2010) (petitioner convicted of capital murder and sentenced to death was entitled to new sentencing hearing in state court); Corcoran v. Wilson, 651 F.3d 611 (7th Cir. 2011) (remand of habeas proceeding from court of appeals to district court was required); Corcoran v. Neal, 783 F.3d 676 (7th Cir. 2015) (finding that trial court reliance only on statutory aggravators in deciding to sentence petitioner to death was reasonable).

7. Rebecca S. Green, Corcoran Death Sentence Still Stands, J. GAZETTE (Mar. 16, 2016, 9:20 AM), https://www.journalgazette.net/news/local/courts/Corcoran-death-sentence-still-stands6138313 [https://perma.cc/ZD74-VEYZ].

8. Id.; Wilson v. Corcoran, 562 U.S. 1 (2010); Corcoran v. Neal, 136 S.Ct. 1493 (2016).

9. Associated Press, Indiana on Death Row for 4 Killings Runs out of Appeals, DAILY HERALD, https://www.dailyherald.com/article/20160708/business/307089868 (last updated July 8 , 2016, 1:42 PM) [https://perma.cc/MA8H-68UV]. 
lethal injections on any of its death row inmates..$^{10}$ Presently, eight male inmates reside on death row in Indiana and one woman under Indiana death penalty is being held in Ohio. ${ }^{11}$ One male's death sentence was set aside, receiving life in prison instead. ${ }^{12}$ Three men on Indiana's death row have exhausted their appeals and await their execution, including Joseph Corcoran. ${ }^{13}$ They are still sentenced to death and will stay on death row until the drugs can be obtained. ${ }^{14}$ This could be indefinitely, as pharmaceutical manufacturers and distributors have made it, and continue to make it, impossible for the United States and state DOCs to obtain the needed drugs. ${ }^{15}$

Capital punishment is a topic that incites intense passion and debate. Indiana is currently presented with a unique opportunity to reevaluate its law, since it cannot obtain the necessary drugs for lethal injections. ${ }^{16}$ Even though many would agree that men like Joseph Corcoran do not deserve to walk outside of prison walls ever again because the crimes they have committed are heinous, our emotions are not to outweigh the integrity of our criminal justice system. Leaving someone on death row indefinitely to wait for their execution after exhausting all appellate remedies is cruel and unusual punishment, particularly when they are left with the threat of death constantly looming overhead. Thus, it violates the Eighth Amendment to the United States Constitution and Article 1, Section 16 of the Indiana Constitution. Therefore, Indiana should abolish the death penalty and grant life without parole sentences in its place.

Part I of this Note gives a background of the history, constitutionality, and methods of the death penalty at both the federal level and at the state level in Indiana. Part II focuses on the application of the death penalty and what has already been deemed "cruel and unusual punishment" by the U.S. Supreme Court. Part II also looks specifically at the standard length an inmate spends on death row and what the Court has said about the timeliness of executions. Part III spotlights the current problem with the death penalty, beginning with a look at Indiana's lack of lethal injection drugs and then analyzing why there is this lack

10. Associated Press, Indiana DOC Doesn't Have the Drugs to Kill Death Row Inmates, WTHR (Aug. 20, 2019, 4:24 AM), https://www.wthr.com/article/indiana-doc-doesnt-have-drugskill-death-row-inmates [https://perma.cc/772E-W7WE] [hereinafter Indiana DOC].

11. See State of Indiana Offenders Sentenced to Death, Ind. DeP'T Corrections, https://www.in.gov/idoc/files/State-of-Indiana-Offenders-Sentenced-to-Death-11.21.19.pdf (last updated Nov. 21, 2019) [https://perma.cc/DE32-SMJ8].

12. Id.

13. Niki Kelly, Executions Waning; 9 Men on Death Row: Lack of Needed Drugs Contributing to Trend, J. GAZETTE (Aug. 4, 2019, 1:00 AM), https://www.journalgazette.net/ news/local/indiana/20190804/executions-waning-9-men-on-death-row [https://perma.cc/3M5XV8QA].

14. Id.

15. Heather Booth, Note, Better the Devil You Know: An Examination of Manufacturer Driven Lethal Injection Drug Shortages, 2 Bus., EnTrepreneurship \& TAX L. ReV. 395, 395 (2018).

16. Id. 
of drugs as well as the role pharmaceutical manufacturers have played in causing the shortage.

Part IV examines where the death penalty is heading in the future, first looking at the federal level and how they plan to execute inmates moving forward, as well as looking at other states that have experienced a lethal injection drug shortage and how they have moved forward with executions in light of this dilemma. Finally, Part V looks specifically at Indiana and the death penalty in the state moving forward. This section starts off with an analysis of whether it is cruel and unusual punishment to leave an inmate on death row indefinitely when there are no legal means to carry out executions. Arguing that this is in fact cruel and unusual punishment, this Note then explains why Indiana should abolish the death penalty and grant life without parole sentences in its place.

\section{BACKGROUND OF THE CONSTITUTIONALITY OF THE DEATH PENALTY}

\section{A. Federal Death Penalty}

The death penalty is currently legal in twenty-seven states and retained by the U.S. government and U.S. military, with three of those states having placed a moratorium on it, as of September 2021. ${ }^{17}$ The Eighth Amendment to the U.S. Constitution is comprised of three clauses and reads, "Excessive bail shall not be required, nor excessive fines imposed, nor cruel and unusual punishments inflicted." " In regard to the last clause of the amendment, the Supreme Court uses four principles in determining whether a punishment is "cruel and unusual": (1) if the punishment, by its severity, is degrading to human dignity; (2) if the punishment is inflicted in an arbitrary fashion; (3) if the punishment is clearly and completely rejected in society; and (4) if the punishment is entirely unnecessary. ${ }^{19}$

Prior to November 2020, the only method of execution the federal government could use when carrying out a death sentence was lethal injection. ${ }^{20}$ However, in November 2020, the Department of Justice issued a new rule, allowing federal executions to be carried out "in any manner consistent with federal law," which includes "electrocution, lethal gas, and firing squad." 21 The Director of the Federal Bureau of Prisons sets the date and time for the execution,

17. State by State, Death Penalty Info. CTR., https://deathpenaltyinfo.org/state-andfederal-info/state-by-state (last visited Sept. 2, 2021) [https://perma.cc/U7UQ-WMMB]. States with the death penalty are Alabama, Arizona, Arkansas, Florida, Georgia, Idaho, Indiana, Kansas, Kentucky, Louisiana, Mississippi, Missouri, Montana, Nebraska, Nevada, North Carolina, Ohio, Oklahoma, South Carolina, South Dakota, Tennessee, Texas, Utah, and Wyoming. Moratorium states are California, Oregon, and Pennsylvania. Colorado abolished the death penalty in 2020, and Virginia did as well in 2021.

18. U.S. CONST. amend. VIII.

19. Furman v. Georgia, 408 U.S. 238, $271-79$ (1972) (Brennan, J., concurring).

20. 28 C.F.R. $\S 26.3(a)(4)(2020)$.

21. Lisa N. Sacco, Cong. Research Serv., IN11474, The Federal Death Penalty 2

(Dec. 1, 2020), https://fas.org/sgp/crs/misc/IN11474.pdf [https://perma.cc/P4JN-S82C]. 
which can be no earlier than sixty days from the sentencing. ${ }^{22}$ If the execution is stayed, a new date must be "promptly" set when the stay is lifted. ${ }^{23}$ Only the President has the power to grant a pardon or a commutation of sentence to a federal death-row inmate. ${ }^{24}$

Lethal injection remains the only method of execution currently utilized by the federal government. ${ }^{25}$ Before the drug shortage began, lethal injection was typically a three-drug "cocktail" consisting of a sodium thiopental to anesthetize, pancuronium bromide to paralyze the muscles, and potassium chloride to stop the heart. ${ }^{26}$ The Supreme Court upheld the three-drug cocktail as constitutional in Baze v. Rees in 2008. ${ }^{27}$

In 1972, the Supreme Court decided Furman v. Georgia, holding that the death penalty, as it was being administered, was unconstitutional. ${ }^{28}$ In this 5-4 decision, each member of the majority filed separate opinions. ${ }^{29}$ The Court found the death penalty was cruel and unusual punishment because it was "so wantonly and so freakishly imposed" amongst the states. ${ }^{30}$ The controlling majority opinions found that the death penalty as then applied was cruel and unusual due to the arbitrary nature of the imposition of death sentences, particularly their discriminatory nature, because identical crimes eligible for the death penalty were not receiving the same sentence. ${ }^{31}$ The other two opinions found the death penalty was in and of itself cruel and unusual punishment. ${ }^{32}$ In order to reinstate the death penalty, states were required to remove arbitrary and discriminatory effects found in their statutes. ${ }^{33}$ After Furman was decided, states quickly restructured their capital punishment statutes to achieve more uniformity, and the Supreme Court began to uphold them as constitutional on a state level four years later, starting with Gregg v. Georgia. ${ }^{34}$

The federal death penalty statute was reinstated in 1988 for a narrow class of offenses. ${ }^{35}$ In 1994, President Bill Clinton signed the Federal Death Penalty Act,

22. 28 C.F.R. $\S 26.3(\mathrm{a})(1)$.

23. $I d$.

24. Background on the Federal Death Penalty, DeAth Penalty Info. CTR., https://deathpenaltyinfo.org/state-and-federal-info/federal-death-penalty/background-on-thefederal-death-penalty (last visited Feb. 21, 2021) [https://perma.cc/8DVQ-53GT].

25. SACCO, supra note 21, at 2.

26. Matt Ford, Can Europe End the Death Penalty in America?, ATLANTIC (Feb. 18, 2014), https://www.theatlantic.com/international/archive/2014/02/can-europe-end-the-death-penalty-inamerica/283790/ [https://perma.cc/N3GL-ZMDH].

27. Baze v. Rees, 553 U.S. 35, 41 (2008).

28. Furman v. Georgia, 408 U.S. 238, 239-40 (1972).

29. Id. at 240 .

30. Id. at 310 (Stewart, J., concurring).

31. See generally id. at 240-58, 306-14 (Stewart, White, \& Douglas, JJ., concurring).

32. See generally id. at 257-306, 314-71 (Brennan \& Marshall, JJ., concurring).

33. Id. at 241 (Douglas, J., concurring).

34. Gregg v. Georgia, 428 U.S. 153, 207 (1976).

35. Federal Death Penalty: Overview, Death Penalty Info. Ctr., 
which expanded the list of offenses one could receive the death penalty for, falling under three categories: (1) homicide offenses, (2) espionage and treason, and (3) non-homicidal narcotics offenses. ${ }^{36}$ In determining whether to impose a death sentence, the fact-finder is to consider certain mitigating factors. ${ }^{37}$ These include, but are not limited to, impaired capacity, duress, the defendant's amount of participation, prior criminal record or lack thereof, mental or emotional disturbance of the defendant, if the victim consented to the criminal conduct that resulted in death, and other factors in the defendant's background, record, or character. $^{38}$

Aggravating factors to be considered when determining if a death sentence is justified differ depending on the crime. Aggravating factors for espionage and treason include, but are not limited to, prior espionage or treason offenses, grave risk to national security, and grave risk of death to another person. ${ }^{39}$ Aggravating factors for homicide include, but are not limited to, death during commission of another crime, certain previous convictions, grave risk of death to additional people, heinous or cruel or depraved manner of committing offense, payment, vulnerability of victim, if the defendant committed the offense against high public officials, and multiple killings or attempted killings. ${ }^{40}$ Finally, aggravating factors for drug offense include, but are not limited to, certain previous convictions, use of firearm, distribution to persons under twenty-one, distribution near schools, using minors for drug trafficking, and mixing with lethal adulterant. ${ }^{41}$

"[A]fter a nearly two-decade hiatus," Attorney General William P. Barr announced the federal government would resume executions of death row inmates, reversing "what had been essentially a moratorium on the federal death penalty." ${ }^{42}$ Since 2003 , no federal death row inmate had been executed. ${ }^{43}$ The inmates were set to be executed using only pentobarbital. ${ }^{44}$ This change came after the Federal Execution Protocol Addendum was passed by the Federal Bureau of Prisons, effective July 25, 2019, which replaced the original three-drug cocktail with simply Pentobarbital Sodium. ${ }^{45}$

https://deathpenaltyinfo.org/state-and-federal-info/federal-death-penalty (last visited Feb. 21, 2021) [https://perma.cc/F6LS-D2GA].

36. 18 U.S.C. $\S \S 3591-98(2018)$.

37. Id. $\S 3592(\mathrm{a})$.

38. Id. § 3592(a)(1-8).

39. Id. $\S 3592(\mathrm{~b})(1-3)$.

40. Id. § 3592(c)(1-16).

41. Id. $\S 3592(\mathrm{~d})(1-8)$.

42. Katie Benner, U.S. to Resume Capital Punishment for Federal Inmates on Death Row, N.Y. TIMES (July 25, 2019), https://www.nytimes.com/2019/07/25/us/politics/federal-executionsdeath-penalty.html [https://perma.cc/UMQ5-QNEQ].

43. Id.

44. Susie Neilson, Lethal Injection Drugs' Efficacy and Availability for Federal Executions, NPR (July 26, 2019, 7:11 PM), https://www.npr.org/2019/07/26/745722219/lethal-injection-drugsefficacy-and-availability-for-federal-executions [https://perma.cc/ZE5C-PJ7L].

45. Benner, supra note 42; see also Addendum to BOP Execution Protocol Federal Death 
However, in November 2019, U.S. District Judge Tanya S. Chutkan of the District of Columbia issued an injunction blocking four of the five scheduled executions for December 2019 and January 2020. ${ }^{46}$ The fifth execution was separately stayed by a different court for an unrelated reason. ${ }^{47}$ Judge Chutkan stated the new protocol of using only pentobarbital "very likely exceeds" the powers established by the Federal Death Penalty Act, and her decision would allow inmates to proceed with their arguments stating as such. ${ }^{48}$ The Federal Death Penalty Act states that federal death sentences "shall [be] . . . implement[ed] . . . in the manner prescribed by the law of the State in which the sentence is imposed." ${ }^{49}$ The four death row inmates to whom Judge Chutkan granted an injunction were convicted in Texas, Missouri, Indiana, and Iowa. ${ }^{50}$ Texas and Missouri use pentobarbital for executions, but Indiana does not. ${ }^{51}$ Because Iowa does not have the death penalty, the courts selected Indiana as the death penalty state for the State of Iowa. ${ }^{52}$

The Department of Justice argued the "'manner' of execution refers to the type of execution - such as lethal injection or an electrocution - rather than each specific detail" - such as which drugs are used in the cocktail. ${ }^{53}$ Judge Chutkan held that using lethal injection is not enough to satisfy the standard under the Federal Death Penalty Act, since " '[m]anner' means 'a mode of procedure or way of acting," "and "[t]he statute's use of the word 'manner' thus includes not just execution method but also execution procedure." 54

The U.S. Court of Appeals for the D.C. Circuit held the Department of Justice did not meet the burden to overturn Judge Chutkan's injunction while an appeal was pending. ${ }^{55}$ The Supreme Court declined to let the Justice Department proceed, denying the government's attempt to "bypass a lower-court ruling that

Sentence Implementation Procedures, Roane v. Gonzales, 269 F.R.D. 1 (D.D.C. 2010) (No. 385-1); U.S. Dep't of Justice, Federal Government to Resume Capital Punishment After Nearly Two Decade Lapse, Just. News (July 25, 2019), https:/www.justice.gov/opa/pr/federal-governmentresume-capital-punishment-after-nearly-two-decade-lapse [https://perma.cc/X6KM-XYB7].

46. Mark Berman \& Robert Barnes, Supreme Court Won't Let Justice Dept. Immediately Resume Federal Executions After Hiatus, WASH. Post (Dec. 6, 2019, 7:55 PM), https:/www.washingtonpost.com/politics/courts_law/supreme-court-wont-let-justice-deptimmediately-resume-federal-executions-after-hiatus/2019/12/06/7103d8e6-1773-11 ea-a6597d69641c6ff7_story.html [https://perma.cc/K2R3-AVQ7].

47. Id.

48. Id.

49. Olivia Covington, Suit over Federal Executions Likely Headed Back to SCOTUS, IND. LAw. (Jan. 22, 2020), https://www.theindianalawyer.com/articles/suit-over-federal-executionslikely-headed-back-to-scotus [https://perma.cc/Q8YH-FJHG].

50. Berman \& Barnes, supra note 46.

51. Id.

52. $I d$.

53. Id.

54. Covington, supra note 49.

55. Berman \& Barnes, supra note 46. 
the department likely exceeded its powers by adopting a new lethal injection protocol." ${ }^{56}$ The Court's ruling allowed a federal appeals court to review the injunction blocking the executions. ${ }^{57}$

The Department of Justice ultimately succeeded in proceeding with the executions scheduled. Starting in July 2020 and continuing through December of that year, ten inmates on federal death row were executed.$^{58}$ It is unclear how or where the federal government obtained pentobarbital. ${ }^{59}$ States' methods in obtaining pentobarbital have been "criticized repeatedly and shrouded in secrecy." ${ }^{, 60}$ Lundbeck, a European company that is one of the main manufacturers of pentobarbital, has not sold the drug to the United States for executions since $2011 .^{61}$

\section{B. Indiana Death Penalty}

Cruel and unusual punishment is also unconstitutional at the state level by incorporation through the Due Process Clause of the Fourteenth Amendment. ${ }^{62}$ Additionally, the Indiana Constitution states, "Cruel and unusual punishments shall not be inflicted. All penalties shall be proportioned to the nature of the offense." ${ }^{63}$

In Indiana, a defendant may only receive the death penalty for the crime of murder if found guilty of murder in addition to the existence of at least one of the eighteen enumerated aggravating circumstances. ${ }^{64}$ The current statutory law on the death penalty in Indiana is found in Indiana Code section 35-50-2-9(a) and provides:

The state may seek either a death sentence or a sentence of life imprisonment without parole for murder by alleging ... the existence of at least one (1) of the aggravating circumstances listed .... In the sentencing hearing after a person is convicted of murder, the state must prove beyond a reasonable doubt the existence of at least one (1) of the aggravating circumstances alleged. However, the state may not proceed

56. Id.

57. Id.

58. SACCO, supra note 21, at 1; Hailey Fuchs, Justice Department Carries Out 10th Execution This Year, N.Y. TIMES (Dec. 11, 2020), https://www.nytimes.com/2020/12/11/us/ politics/alfred-bourgeois-death-penalty.html [https://perma.cc/SBQ3-NVMY].

59. Neilson, supra note 44.

60. Chip Brownlee, The Federal Government Plans to Revive the Death Penalty After 16 Years, SLATE (July 25, 2019, 3:38 PM), https://slate.com/news-and-politics/2019/07/justicedepartment-bill-barr-orders-revival-federal-executions-lethal-injection.html [https://perma.cc/MJ6X-T7EK].

61. Neilson, supra note 44.

62. U.S. CONST. amend. XIV.

63. IND. Const. art. $1, \S 16$.

64. Death Penalty Facts, Ind. Pub. DefEnder CouncIL, https:/www.in.gov/ipdc/files/Factsabout-the-death-penalty-.pdf (last updated Feb. 27, 2019) [https://perma.cc/R9G6-8XRZ]. 
against a defendant under this section if a court determines at a pretrial hearing under IC 35-36-9 that the defendant is an individual with an intellectual disability. ${ }^{65}$

The referenced list of aggravating circumstances is located in Indiana Code section 35-50-2-9(b). These include, but are not limited to: committing the murder by intentionally killing the victim while committing or attempting to commit one of the listed crimes ${ }^{66}$; committing the murder by "lying in wait" ${ }^{967}$; being hired or hiring to kill ${ }^{68}$; being "convicted of another murder" ${ }^{\prime \prime}$; committing "another murder, at any time, regardless of . . . convict[ion]" "; ; dismemberment of the victim ${ }^{71}$; burning, mutilating, torturing, or decapitating the victim while the victim was alive ${ }^{72}$; murdering a victim less than twelve years of age ${ }^{73}$; and if "the victim was pregnant and the murder resulted in the intentional killing of a fetus that has attained viability." ${ }^{\prime 7}$

When a defendant has been convicted of murder, the prosecution must present evidence to the jury regarding the existence of alleged aggravating and mitigating circumstances in order to seek the death penalty. ${ }^{75}$ The jury then deliberates to determine its recommendation of a sentence, and must return a unanimous agreement of either sentencing the defendant to death or sentencing the defendant to life without parole. ${ }^{76}$ If the jury finds an aggravating circumstance existed but does not unanimously agree on a sentence, the court is free to determine the defendant's sentence. ${ }^{77}$ The ability to seek or grant life without the possibility of parole was created in 1993 when the Indiana General Assembly authorized this sentencing option in capital murder cases. ${ }^{78}$

In Indiana, all state executions of male inmates occur at the Indiana State Prison in Michigan City. ${ }^{79}$ Indiana has utilized three official methods of execution during the state's history. ${ }^{80}$ Until 1913 , the primary method of execution was

65. IND. CODE $§ 35-50-2-9$ (a) (2020).

66. Id. $\S 35-50-2-9(\mathrm{~b})(1)(\mathrm{A}-\mathrm{K})$.

67. Id. $\S 35-50-2-9(\mathrm{~b})(3)$.

68. Id. $\S 35-50-2-9(\mathrm{~b})(4-5)$.

69. Id. $\S 35-50-2-9(\mathrm{~b})(7)$.

70. Id. $\S 35-50-2-9(\mathrm{~b})(8)$.

71. Id. $\S 35-50-2-9(\mathrm{~b})(10)$.

72. Id. $\S 35-50-2-9(\mathrm{~b})(11)$.

73. Id. $\S 35-50-2-9(\mathrm{~b})(12)$.

74. Id. $\S 35-50-2-9(\mathrm{~b})(16)$.

75. Death Penalty Facts, supra note 64.

76. Id.

77. $I d$.

78. Id.

79. State and Federal Info: Indiana, Death Penalty Info. Ctr., https://deathpenaltyinfo. org/state-and-federal-info/state-by-state/indiana (last visited Feb. 21, 2021) [https://perma.cc/ MJ4M-GBLR].

80. Id. 
hanging. ${ }^{81}$ In 1913 , the electric chair became the primary method and continued until $1995 .{ }^{82}$ Lethal injection then began and is now the method currently used ${ }^{83}$ The rate of executions in Indiana has steadily dwindled; since 1995, only nineteen inmates have been executed by lethal injection. ${ }^{84}$ An execution has not occurred in Indiana since $2010 .^{85}$

In 2014, Indiana changed its traditional lethal injection cocktail because its supply had expired. ${ }^{86}$ Additionally, there was a nationwide shortage of the anesthetic drug of choice, sodium thiopental. ${ }^{87}$ Sodium thiopental has a shelf-life of four years, making it difficult to stock up on the drug. ${ }^{88}$ Indiana switched to a new three-drug cocktail, consisting of Brevital, pancuronium bromide, and potassium chloride ${ }^{89}$ At the time of the change, no inmate in the United States had ever been executed with Brevital. ${ }^{90}$ In 2018, the Indiana Supreme Court upheld the state's utilization of this experimental mixture of lethal injection drugs; however, these drugs are also increasingly difficult to acquire. ${ }^{91}$

\section{DEATH PENALTY APPLICATION}

\section{A. What Has Been Deemed "Cruel and Unusual Punishment"}

The United States Supreme Court has held that in some instances the application of the death penalty constitutes cruel and unusual punishment. The Court has abolished capital punishment for mentally disabled offenders, ${ }^{92}$ juvenile offenders, ${ }^{93}$ and those convicted of raping a child where death was not intended or was not the result. ${ }^{94}$

The constitutionality of lethal injection in general was examined by the Court

81. Id.

82. Id.

83. Id.

84. Niki Kelly, supra note 13.

85. State and Federal Info: Indiana, supra note 79.

86. Niki Kelly, supra note 13.

87. Associated Press, Indiana Use of New Execution Drug Draws Opposition, CBS News (May 31, 2014, 3:40 PM), https://www.cbsnews.com/news/indiana-use-of-new-execution-drugdraws-opposition [https://perma.cc/LLU5-L2S4].

88. Ford, supra note 26.

89. Jordan Fischer, Indiana Supreme Court Rules State May Use New Drug in Lethal Injection Cocktail, RTV6 IndianAPOLIS (Feb. 13, 2018, 3:36 PM), https://www.theindychannel. $\mathrm{com} /$ news/local-news/crime/indiana-supreme-court-rules-state-may-use-new-drug-in-lethalinjection-cocktail [https://perma.cc/K6XF-2W7A].

90. Id.

91. Id.

92. Atkins v. Virginia, 536 U.S. 304 (2002).

93. Roper v. Simmons, 543 U.S. 551 (2005).

94. Kennedy v. Louisiana, 554 U.S. 407 (2008). 
in 2008 in Baze v. Rees, ${ }^{95}$ and later upheld in 2015 in Glossip v. Gross. ${ }^{96}$ In deciding that lethal injection did not constitute cruel and unusual punishment, the Court in Baze applied an "objectively intolerable risk" test to determine if the method of execution was unconstitutional. ${ }^{97}$ Under this test, for an execution to be considered cruel and unusual punishment, the method must present a "substantial ... [or] objectively intolerable risk of harm." "98

In Glossip, Oklahoma death-row inmates argued that the three-drug cocktail of the lethal injection protocol "create[d] an unacceptable risk of severe pain." 99 Oklahoma was unable to obtain sodium thiopental or pentobarbital for their executions, so they used a 500-milligram dose of midazolam as the first drug in the three-drug cocktail. ${ }^{100}$ The Court upheld the lethal injection protocol stating the inmates had failed to establish there was any substantial risk of harm compared to other methods of executions. ${ }^{101}$

However, in Justice Stephen Breyer's dissent, he urged the Court to reconsider the constitutionality of the death penalty in general. ${ }^{102}$ Justice Breyer stated the circumstances and evidence of the death penalty's application have changed drastically and therefore should be reexamined. ${ }^{103}$ He wrote, "Today's administration of the death penalty involves three fundamental constitutional defects: (1) serious unreliability, (2) arbitrariness in application, and (3) unconscionably long delays that undermine the death penalty's penological purpose," making the death penalty cruel and unusual punishment. ${ }^{104}$

Delving deeper into the third factor, Justice Breyer noted that the delay derives from the Constitution's own demands - the special need for reliability and fairness, and that every safeguard be observed during the appellate process. ${ }^{105} \mathrm{In}$ Justice Breyer's view, the procedural necessities take time to implement, and they cannot be abandoned without compromising fairness and reliability; thus, the Court should deal with the harms caused by delay itself. ${ }^{106}$ The average length of delay between sentencing and execution in 1960 was two years; in 2004, eleven years; and in 2014, eighteen years. ${ }^{107}$ In 2017, the last time the Death Penalty Information Center published the average amount of time an inmate spends on death row, the average time between sentencing and execution was just over

\footnotetext{
95. See Baze v. Rees, 553 U.S. 35 (2008).

96. Glossip v. Gross, 576 U.S. 863 (2015).

97. Baze, 553 U.S. at 37.

98. Id. at 50 (citation and internal quotation marks omitted).

99. Glossip, 576 U.S. at 867.

100. Id. at 863 .

101. Id.

102. Id. at 914 (Breyer, J., dissenting).

103. Id. at 907.

104. Id. at 908-09.

105. Id. at 923 .

106. Id.

107. Id.
} 
twenty years. ${ }^{108}$ These lengthy delays are "especially cruel" because they "subject[] death row inmates to decades of especially severe, dehumanizing conditions of confinement," and they undermine the rationale of even having the death penalty. ${ }^{109}$

Additionally, certain standards of confinement for inmates have been called into question as constituting cruel and unusual punishment. In 2019, the Fourth Circuit Court of Appeals ruled that the conditions of death row solitary confinement in Virginia prisons violated the Eighth Amendment. ${ }^{110}$ The conditions included having inmates spend twenty-three hours of the day in a seventy-one-square-foot cell, with one hour of outdoor recreation allotted in a "steel-and-wire-mesh cage[]," only five days a week. ${ }^{11}$ The court held that prolonged periods of isolation created "a substantial risk of serious psychological and emotional harm" and found that "prolonged solitary [wa]s linked to paranoia, hallucinations, depression, sleep disturbance, suicidal fixation, anxiety, irritability, rage and depression." 112

The conditions of Indiana's death row have been investigated in the past, specifically by the American Civil Liberties Union (ACLU). ${ }^{113}$ In 2008, the ACLU said the conditions were "grossly inadequate" because the inmates were being "denied access to basic medical care, basic mental health care services," and dental care, and officials were not responding sufficiently to medical emergencies of inmates. ${ }^{14}$ The ACLU also found inmates were often exposed to significant psychological distress from constant screaming and banging from other parts of the institution, as well as fire alarms and strobe lights that went off for over an hour every week. ${ }^{15}$ Further, the prisoners do not have many opportunities to interact with others. ${ }^{116}$ The inmates have "no recreation," but are allotted three times a week to go out of their cells into "cages," according to a spiritual advisor. ${ }^{117}$

108. Time on Death Row, Death Penalty Info. Ctr., https://deathpenaltyinfo.org/deathrow/death-row-time-on-death-row (last visited Feb. 21, 2021) [https://perma.cc/TK6X-4DTE].

109. Glossip, 576 U.S. at 925 (Breyer, J., dissenting) (citations omitted).

110. Debra Cassens Weiss, Solitary Confinement Conditions Violated Death-Row Inmates' Eighth Amendment Rights, 4th Circuit Rules, ABA J. (May 6, 2019, 11:00 AM), $\mathrm{http}$ //www.abajournal.com/news/article/solitary-confinement-conditions-violated-death-rowinmates-constitutional-rights-appeals-court-rules [https://perma.cc/8CP4-FUTY].

111. Id.

112. Id.

113. Death Row Conditions by State, Indiana, Death Row Conditions BY St., http://deathrowconditions.web.unc.edu/midwest-region/indiana/ (last visited Feb. 21, 2021) [https://perma.cc/DL9D-WA7K].

114. $I d$.

115. Id.

116. Id.

117. Id. 


\section{B. Is There a Standard for Timeliness of an Execution?}

There is no uniform standard for "timeliness" of an execution of a death row inmate. Over the years, the opinion of the U.S. Supreme Court has dramatically shifted in regard to how long the Court considers it to be cruel and unusual punishment to have an inmate wait on death row.

In 1890, James J. Medley submitted an application for a writ of habeas corpus to the U.S. Supreme Court, in which he sought to be relieved from his imprisonment and sentence of execution in Colorado. ${ }^{118}$ Medley had been sentenced to death on November 29, 1889, and his execution was scheduled for the fourth week in December that same year. ${ }^{119}$ Justice Samuel Miller wrote the majority opinion for the Court, stating:

Nor can we withhold our conviction of the proposition that when a prisoner sentenced by a court to death is confined in the penitentiary awaiting the execution of the sentence, one of the most horrible feelings to which he can be subjected during that time is the uncertainty during the whole of it, which may exist for the period of four weeks, as to the precise time when his execution shall take place. ${ }^{120}$

The Court held that Medley's imprisonment of four weeks awaiting execution violated the Constitution and freed him. ${ }^{121}$

Fast-forward to 1972, in Furman v. Georgia, three petitioners had been convicted of either murder or rape in Georgia (two petitioners) and Texas (one petitioner). ${ }^{122}$ The Court found that the death penalty, as it was being administered, was unconstitutional; and the death sentence for each petitioner was set aside. ${ }^{123}$ In a concurring opinion, Justice William Brennan acknowledged a previous statement by Justice Felix Frankfurter that said, "[T]he onset of insanity while awaiting execution of a death sentence is not a rare phenomenon." 124 Justice Brennan further wrote, "No other existing punishment is comparable to death in terms of physical and mental suffering. ... [T] $[$ he prospect of pending execution exacts a frightful toll during the inevitable long wait between the imposition of sentence and the actual infliction of death." ${ }^{\prime 25}$

Over a century after Medley, in 2002, the U.S. Supreme Court denied a petition for a writ of certiorari by Petitioner Charles Foster who had spent more than twenty-seven years on death row. ${ }^{126}$ Justice Breyer disagreed with the

118. In re Medley, 134 U.S. 160, 161 (1890).

119. Id. at 161-62.

120. Id. at 172 .

121. Id. at 175 .

122. Furman v. Georgia, 408 U.S. 238, 238 (1972).

123. Id. at 239-40.

124. Id. at 288-89 (Brennan, J., concurring) (quoting Solesbee v. Balkcom, 339 U.S. 9, 14 (1950) (Frankfurter, J., dissenting)).

125. Id. at 287-88.

126. Foster v. Florida, 537 U.S. 990, 123 S. Ct. 470 (2002). 
majority, and stated in his dissenting opinion that "Foster ha[d] endured an extraordinarily long confinement under sentence of death." ${ }^{27} \mathrm{He}$ asserted that "the combination of uncertainty of execution and long delay is arguably "cruel,", and that it "can inflict 'horrible feelings' and an 'immense mental anxiety amounting to a great increase of the offender's punishment." ${ }^{128}$ In Justice Breyer's opinion, executing Foster after his lengthy stay on death row would subject him not only to punishment of death, but also to "more than a generation spent in death row's twilight." ${ }^{29}$ Because Justice Breyer believed this opened up a genuine question of whether this was cruel and unusual punishment, he opposed the denial of certiorari. ${ }^{130}$

In 2009, William Thompson petitioned for a writ of certiorari to the U.S. Supreme Court regarding his death sentence. ${ }^{131}$ When Thompson presented to the Court in 2009, he had spent thirty-two years on death row; the Court, however, denied his petition. ${ }^{132}$ Justice John Paul Stevens issued a statement emphasizing the importance of the issue raised, arguing that excessive time spent on death row amounted to cruel and unusual punishment. ${ }^{133} \mathrm{He}$ expressed that the Court's experience during the past thirty years "demonstrated that delays in statesponsored killings are inescapable and that executing defendants after such delays is unacceptably cruel." " 34 He further went on to state that "[t]his inevitable cruelty, coupled with the diminished justification for carrying out an execution after the lapse of so much time, reinforce[d his] opinion" that decisions to still have the death penalty as a part of our law are the result of "habit and inattention rather than an acceptable deliberative process." 135

In 2011, Justice Breyer again dissented when the majority refused to stay the execution of Manuel Valle, who had been convicted of murdering a police officer. ${ }^{136}$ Valle asked the Court to consider if an execution following decades of incarceration on death row violated the Constitution. ${ }^{137}$ Justice Breyer stated that the Court should consider the claim, and said of the thirty-three years Valle had spent on death row under threat of execution: "I have little doubt about the cruelty of so long a period of incarceration under sentence of death." 138

127. Id. at 472 (Breyer, J., dissenting).

128. Id. at 471 (quoting In re Medley, 134 U.S. 160, 172 (1890)).

129. Id. at 472 .

130. Id.

131. Thompson v. McNeil, 556 U.S. 1114, 129 S. Ct. 1299 (2009).

132. $I d$.

133. Id. at 1114-16 (Stevens, J., respecting the denial of the petition for writ of certiorari).

134. Id. at 1116.

135. Id. (quoting Baze v. Rees, 553 U.S. 35, 78 (2008) (Stevens, J., concurring in judgment)).

136. Valle v. Florida, 564 U.S. 1067, 1067-69 (2011) (Breyer, J., dissenting).

137. Id. at 1067 .

138. Id. 


\section{THE CURRENT PROBLEM}

\section{A. Indiana DOC's Current Problem with Execution Drugs}

Currently, Indiana's death row consists of eight men: Joseph Corcoran (convicted of killing four men in 1997), William Gibson (a serial killer convicted of murdering three women between 2002-2012, and was sentenced to death in two cases), Michael Dean Overstreet (convicted of killing a college student in 1997), Benjamin Ritchie (convicted of killing a police officer in 2000), Roy Ward (convicted of raping and killing a teenager in 2001), Kevin Isom (convicted of killing his wife and her two children in 2007), Jeffrey Weisheit (convicted of killing two children in 2010), and Eric Holmes (convicted of stabbing two supervisors to death at his workplace in 1989). ${ }^{139}$ The death sentence of Fredrick Baer (convicted of killing a woman and her four-year-old daughter in 2004) was set aside, and he was resentenced to life in prison. ${ }^{140}$ Three of these inmates-Joseph Corcoran, Benjamin Ritchie, and Roy Ward-have exhausted their appeals. ${ }^{141}$ Joseph Corcoran has been on death row for twenty-two years, Benjamin Ritchie for nineteen years, and Roy Ward for eighteen years. ${ }^{142}$

As officially announced on August 18, 2019, the IDOC does not have the necessary drugs to perform any executions on its death row inmates, including those who have exhausted their appeals. ${ }^{143}$ Attorney General Curtis Hill has not yet asked for execution dates for these men because of the lack of necessary drugs. ${ }^{144}$ Thus, these men sit on death row with no execution date and no further appellate remedies.

The shortage of the necessary lethal injection drugs is affecting executions nationwide, on both state and federal levels. Specifically, there is a nationwide shortage of the anesthetic drug of choice that is a part of the three-drug cocktail typically used for lethal injections, sodium thiopental. ${ }^{145}$ This "has thrown capital punishment in the United States into disarray, delaying executions and forcing the change of execution protocols." ${ }^{146}$ The anesthetic enables the lethal injection to be conducted in a "humane manner. Without the anesthetic, the prisoner experiences the excruciating pain caused by the second two drugs, which has

139. Niki Kelly, supra note 13.

140. Id.; Traci L. Miller, Baer Resentenced to Life for 2004 Murder of Woman and Child near Lapel, HeRALD Bull. (Aug. 1, 2019), https:/www.heraldbulletin.com/news/baer-resentenced-tolife-for-2004-murder-of-woman-and-child-near-lapel/article_0160190c-b47a-11 e9-a6caa341e101c814.html [https://perma.cc/T7PG-RSKX].

141. Miller, supra note 140.

142. Id.

143. Indiana DOC, supra note 10.

144. Niki Kelly, supra note 13.

145. Jennifer Horne, Lethal Injection Drug Shortage, Council St. Gov'Ts (July-Aug. 2017), https://www.csg.org/pubs/capitolideas/enews/issue65_4.aspx [https://perma.cc/2RTC-HSBZ].

146. Id. 
been described as the chemical equivalent of burning at the stake."147

\section{B. Pharmaceutical Manufactures Dilemma Causing the Shortage}

Typically, the three-drug lethal injection cocktail consists of sodium thiopental, pancuronium bromide, and potassium chloride. ${ }^{148}$ Hospira was the sole company that provided sodium thiopental in the United States until 2009. ${ }^{149} \mathrm{In}$ 2009, Hospira terminated production of sodium thiopental at its U.S. plant. ${ }^{150}$ The company stated that it had plans to start production again in Italy, but these plans became unfeasible due to new Italian government regulations. ${ }^{151}$ Hospira's announcement to stop producing the drug came after "a global campaign by death penalty opponents and pressure by Italian government officials."152 Officials demanded the company monitor its drug all the way to the very final user and prevent the drug's use in executions. ${ }^{153}$ At that time, Hospira left the thiopental market completely. ${ }^{154}$

After Hospira left the market, states began obtaining sodium thiopental from a middleman source in London. ${ }^{155}$ However, this method was also ceased after the court decided in Beaty v. FDA that "foreign importation of sodium thiopental posed a serious risk of contamination and counterfeit, thereby violating federal Food, Drug, and Cosmetic Act protocols."156

Additionally, when Hospira left the market, some states, as well as the federal government, turned to a pentobarbital-only protocol as a substitute to execute inmates. ${ }^{157}$ One brand name for pentobarbital is Nembutal ${ }^{\circledR}$, which is trademarked and manufactured by the Danish pharmaceutical company Lundbeck, and is now produced by Akorn Pharmaceuticals. ${ }^{158}$ This is the only injectable form of pentobarbital approved for sale in the United States, and Akorn has previously stated it will not sell pentobarbital to states that use its drug for capital

147. Erin Kelly, Re-Evaluating the Regulation of Executions, 36 Syracuse J. ScI. \& TeCH. L. 84, 93-94 (2019-2020) (citing Glossip v. Gross, 576 U.S. 863, 949 (2015) (Sotomayor, J., dissenting)).

148. Ford, supra note 26.

149. Horne, supra note 145.

150. Booth, supra note 15, at 403.

151. Id.

152. Horne, supra note 145.

153. Booth, supra note 15 , at 403.

154. Id.

155. Erin Kelly, supra note 147 , at 94 (citation omitted).

156. Id. at 94-95 (citation omitted).

157. David Jolly, Danish Company Blocks Sale of Drug for U.S. Executions, N.Y. TimES (July 1, 2011), https://www.nytimes.com/2011/07/02/world/europe/02execute.html [https://perma.cc/ T3QV-GSDT].

158. Id.; James Gibson \& Corinna Barrett Lain, Death Penalty Drugs and the International Moral Marketplace, 103 GEO. L.J. 1215, 1228 n.71 (2015). 
punishment executions. ${ }^{159}$ Thus, states turned to compounding pharmacies, which are able to create their own drugs without supervision by the Food and Drug Administration (FDA), to get their drug supplies. ${ }^{160}$

As major advocates against capital punishment, the European Union (EU) has been publicly calling for the "universal abolition" of the death penalty for a long time. ${ }^{161}$ The EU often petitions the U.S. legislature to stop executions and files amicus curiae briefs in front of the U.S. Supreme Court. ${ }^{162}$ EU agencies also contribute millions of dollars to anti-death penalty organizations. ${ }^{163}$ In 2010 , the United Kingdom restricted any exportation of lethal injection drugs to the United States. ${ }^{164}$ In 2011, the EU banned the exportation of pharmaceuticals that could potentially be used in capital punishment executions. ${ }^{165}$ Their decision was to "contribute[] to the wider EU efforts to abolish the death penalty worldwide."166

Additionally, whenever a state institutes a new lethal injection drug procedure, European countries almost immediately ban the exportation of that specific drug to the United States. ${ }^{167}$ For example, in May 2012, Missouri announced it was going to use a single drug for executions called Propofol; and, in July of that year, the United Kingdom banned exports of Propofol to the United States. ${ }^{168}$ Missouri's governor ordered Missouri to stop using the drug in their lethal injection cocktail when the EU also threatened to issue an export ban. ${ }^{169}$

European drug manufacturers themselves have been open regarding their vigorous opposition to capital punishment and any use of their products in conducting such executions. ${ }^{170}$ Smaller manufacturers throughout the world have refused to sell sodium thiopental as well as other drugs used in executions to the United States because of "activist pressure, the fear of lawsuits, and their ethical [and moral] obligations." "171

In 2013, a group of death row inmates from Arizona, California, and

159. Erica Hunzinger, Secret Sedative: How Missouri Uses Pentobarbital in Executions, ST. Louis PuB. RADIO (Aug. 18, 2017), https://news.stlpublicradio.org/post/secret-sedative-howmissouri-uses-pentobarbital-executions\#stream/0 [https://perma.cc/U3D6-KVWJ]; Jolly, supra note 157.

160. Erin Kelly, supra note 147, at 95 (citation omitted).

161. Ford, supra note 26.

162. Id.

163. Id.

164. Jon Stone, America is Running Out of Lethal Injection Drugs Because of a European Embargo to End the Death Penalty, INDEPENDENT (Mar. 13, 2015, 5:08 PM), https://www. independent.co.uk/news/world/americas/america-is-running-out-of-lethal-injection-drugs-becauseof-a-european-embargo-to-end-the-death-10106933.html [https://perma.cc/72QD-TC6J].

165. Ford, supra note 26.

166. Stone, supra note 164.

167. See generally Gibson \& Lain, supra note 158.

168. Ford, supra note 26.

169. Id.

170. Gibson \& Lain, supra note 158, at 1217.

171. Ford, supra note 26. 
Tennessee sued the FDA and the Department of Health and Human Services, arguing that allowing an importation of unregulated sodium thiopental for use in lethal injections violated the Food, Drug, and Cosmetic Act and the Administrative Procedure Act. ${ }^{172}$ The U.S. District Court for the District of Columbia granted a permanent injunction enjoining the FDA from allowing importation of "misbranded or unapproved" sodium thiopental, and the U.S. Court of Appeals affirmed the judgment, finding that the FDA acted "in derogation of [its] duties by permitting such [an] importation." 173

In 2018, the Indiana Supreme Court ruled that Indiana could use Brevital in a new lethal injection cocktail mixture, upholding lower court decisions. ${ }^{174}$ However, Par Pharmaceutical, the manufacturer of Brevital, announced shortly after Indiana chose Brevital in 2014 that it would "try to block efforts to use [their] drug in executions" and said Brevital is "intended to be used as an anesthetic in life-sustaining procedures." $" 175$ The company said Indiana's proposed use was "contrary to [their] mission" to improve the quality of life. ${ }^{176}$

\section{DEATH PENALTY NOW AND IN THE FUTURE}

\section{A. The Federal Government's Plans for Future Executions}

The federal government resumed executions in 2020 at the federal penitentiary in Terre Haute, Indiana, after an almost two decade hiatus. ${ }^{177}$ Instead of the traditional three-drug cocktail or an experimental mixture of drugs, the federal executions were to use only one drug - pentobarbital. ${ }^{178}$ The change came after "botched executions" on the state level using experimental mixtures instigated many lawsuits to be filed where "the drugs used were ineffective or caused severe suffering before death"179 (discussed more in the following section).

As previously noted, the U.S. Supreme Court originally refused to let the Justice Department proceed with these executions, and the Court denied the government's attempt to "bypass a lower-court ruling that the department likely exceeded its powers by adopting a new lethal injection protocol" of using only

172. Cook v. FDA, 733 F.3d 1 (D.C. Cir. 2013); see Food, Drug, and Cosmetic Act, 21 U.S.C. $\S \S$ 301-399 (2020); Administrative Procedure Act, 5 U.S.C. $\S \S 551-559$ (2020).

173. Cook, 733 F.3d at 3, 12. The district court also "ordered the FDA to notify state correctional departments that the use of imported thiopental is unlawful and that existing stocks must be sent to the FDA." Id. at 3. But the court of appeals "vacate[d] the portion of [the District Court's] remedial order pertaining to thiopental already in the possession of the states." Id.

174. Fischer, supra note 89; see Ward v. Carter, 90 N.E.3d 660 (Ind. 2018)).

175. Fischer, supra note 89.

176. Id.

177. Benner, supra note 42.

178. Id.

179. Id. 
pentobarbital. ${ }^{180}$ However, the federal government was able to ultimately proceed with executions, and has since executed, using only pentobarbital, ten federal death row inmates in 2020 and three in 2021 (as of September 1st). ${ }^{181}$

\section{B. Other States and the Drug Shortage Dilemma}

With countries imposing strict export regulations on drugs that could potentially be used for capital punishment, and pharmaceutical manufacturers implementing policies that do not allow their drugs to be used for capital punishment, states have begun to transition to alternative ways to execute their death row inmates. Austin Sarat, a death penalty expert and professor at Amherst College, stated, "What['s] happening in various states that are trying to continue to use lethal injection is a period of experimentation on human beings." 182

One of the alternatives that states have implemented is the same that the federal government utilized in 2020 - using only pentobarbital. States started using only pentobarbital in 2011 because of the shortage of sodium thiopental. ${ }^{183}$ Fourteen states use or have used this single drug to carry out executions: Alabama, Arizona, Delaware, Florida, Georgia, Idaho, Mississippi, Missouri, Ohio, Oklahoma, South Carolina, South Dakota, Texas, and Virginia. ${ }^{184}$

Where states obtain pentobarbital is wrapped in secrecy. ${ }^{185}$ Because of the secrecy, experts argue that it is difficult to know whether these capital punishment processes are constitutional, since their source, effects, and effectiveness are essentially unknown. ${ }^{186}$ Due to large manufacturers of pentobarbital refusing to sell to the United States, there have been troubling results when using pentobarbital at the state level because of the unregulated background of the drug, usually obtained from compounding pharmacies. For example, the Texas DOC used a version of pentobarbital that had been created by one such compounding pharmacy. ${ }^{187}$ Reports indicated Texas inmates that had been injected with this pentobarbital "writhed on the floor, screamed in pain and said they could feel

180. Berman \& Barnes, supra note 46; see supra Section I.A.

181. Fuchs, supra note 58; Execution List 2021, DeAth Penalty Info. Ctr., https://deathpenaltyinfo.org/executions/2021 (last updated Sept. 1, 2021) [https://perma.cc/3WT87ZM7].

182. Adam Serwer, Lethal Drugs Injected 15 Times in Botched Arizona Execution, MSNBC (Aug. 4, 2014, 9:27 AM), http://www.msnbc.com/msnbc/lethal-drugs-injected-15-times-botchedarizona-execution [https://perma.cc/8Q68-K4Y4].

183. Josiah Bates, Why the Justice Department's Plan to Use a Single Drug for Lethal Injections Is Controversial, TIME (July 29, 2019), https://time.com/5636513/pentobarbitalexecutions-justice-department/ [https://perma.cc/JF2F-3W49].

184. Overview of Lethal Injection Protocols, Death Penalty Info. Ctr., https:// deathpenaltyinfo.org/executions/lethal-injection/overview-of-lethal-injection-protocols (last visited Feb. 21, 2021) [https://perma.cc/A5H8-VSG2].

185. Brownlee, supra note 60.

186. Hunzinger, supra note 159.

187. Neilson, supra note 44. 
themselves 'burning." "188 In 2012, the South Dakota DOC obtained pentobarbital from a local compounding pharmacy, which was later determined to be contaminated with fungus, causing the injected inmate to snore and then remain open-eyed as he was executed. ${ }^{189}$ In yet another execution in Oklahoma in 2014, the DOC swapped sodium thiopental with pentobarbital in the drug mixture, to which Michael Wilson stated he could "feel his 'whole body burning" before death. ${ }^{190}$

As previously noted, compounding pharmacies are another popular method that states use. ${ }^{191}$ The companies that produce such drug mixtures are not heavily regulated, and therefore they pose significant risks. ${ }^{192}$ The FDA does not verify the drugs, and there have been problematic results. ${ }^{193}$ In 2001, in a study conducted by the FDA, twenty-nine drugs from compounding pharmacies were tested, and ten of them failed at least one of the quality tests. ${ }^{194}$ This is compared to drugs subject to FDA regulation, where only four out of three thousand had quality problems. ${ }^{195}$ Regardless of this, the number of states reaching out to compounding pharmacies to obtain the drugs for lethal injections only continues to increase with alarming results. ${ }^{196}$

Back when the shortage of sodium thiopental began, a widespread choice by states was replacing sodium thiopental with midazolam as the first drug of the cocktail. ${ }^{197}$ The change to midazolam also came under "intense scrutiny." 198 Midazolam "is not approved by the FDA for use as the sole drug to produce and maintain anesthesia in surgical proceedings." DOCs that midazolam has side effects that could be excruciating and was not an effective painkiller. ${ }^{200}$ This is because midazolam "cannot render a person [completely] unconscious" and "cannot relieve pain."201

In 2014, in Oklahoma, Clayton Lockett was injected with a combination of midazolam, vecuronium bromide, and potassium chloride (an "untested

188. Id.

189. Deborah W. Denno, Lethal Injection Chaos Post-Baze, 102 GEO. L.J. 1331, 1376 (2014).

190. Ford, supra note 26.

191. See supra Section III.B.

192. Bates, supra note 183.

193. Booth, supra note 15, at 418.

194. Sharon Begley, Insight: How Compounding Pharmacies Rallied Patients to Fight Regulation, REUTERS (Oct. 16, 2012, 12:05 AM), https:/www.reuters.com/article/us-usa-healthmeningitis-compounding/insight-how-compounding-pharmacies-rallied-patients-to-fightregulation-idUSBRE89F05Y20121016 [https://perma.cc/8YGY-HL9B].

195. Id.

196. See Denno, supra note 189.

197. Brownlee, supra note 60.

198. Id.

199. Erin Kelly, supra note 147 , at 96.

200. See id.

201. Id. at 98; see Arthur v. Dunn, 137 S. Ct. 725, 726 n.2 (2017). 
blend"). ${ }^{202}$ He was thought to be unconscious, but woke up and began thrashing around and mumbling. ${ }^{203}$ During the injection, Lockett's vein exploded, causing him extreme pain, ${ }^{204}$ and he died from a heart attack forty-three minutes later. ${ }^{205}$

On July 23, 2014, in Arizona, Joseph Wood's death took nearly two hours, and consisted of fifteen injections of an "experimental lethal drug cocktail" of hydromorphone and midazolam. ${ }^{206}$ Witnesses at Wood's execution observed that he spent an hour "gasping and snorting." 207

The Ohio DOC also experimented with midazolam in 2014, first using it in a two-drug cocktail of midazolam and hydromorphone on inmate Dennis McGuire. ${ }^{208}$ McGuire spent eleven minutes - after being administered the drugs - gasping and choking with his fists clenched. ${ }^{209}$ According to the suit brought later by McGuire's family, witnesses said McGuire "grunted and fought for air, 'snorting, gurgling and arching his back."' ${ }^{210}$ The priest who witnessed the execution stated McGuire had suffered greatly. ${ }^{211}$ According to the suit brought by McGuire's family, a prison official "mouthed 'I'm sorry" to his relatives inside of the witness execution chamber. ${ }^{212}$

In 2019, Ohio's governor actually stopped an execution that planned to use midazolam after reviewing the findings of Dr. Mark Edgar. ${ }^{213}$ Dr. Edgar had examined twenty-eight autopsy reports of executed inmates over the past few years from across the country. ${ }^{214}$ His results exposed that twenty-four of the inmates showed signs of pulmonary edema, which is an accumulation of fluid in the lungs that feels like drowning. ${ }^{215}$ There was also "bloody froth that oozed from the lungs" during several of the autopsies. ${ }^{216}$ According to Dr. Edgar's report, this was "evidence that the buildup had been sudden, severe, and

202. Bates, supra note 183 .

203. Ziva Branstetter, Eyewitness Account: A Minute-by-Minute Look at What Happened During Clayton Lockett's Execution, Tulsa WorLd (May 1, 2014), https://www.tulsaworld. $\mathrm{com} /$ news/state/eyewitness-account-a-minute-by-minute-look-at-what-happened/article_f7764efcd036-11e3-af7e-0017a43b2370.html?_dc=322276439517.73645 [https://perma.cc/YSX3-KFD7].

204. Id.

205. Bates, supra note 183 .

206. Serwer, supra note 182.

207. Id.

208. Ford, supra note 26.

209. Id.

210. Liliana Segura, Ohio's Governor Stopped an Execution over Fears It Would Feel like Waterboarding, INTERCEPT (Feb. 7, 2019, 7:55 AM), https://theintercept.com/2019/02/07/d eath-penalty-lethal-injection-midazolam-ohio/ [https://perma.cc/NKV9-R6HV].

211. Ford, supra note 26.

212. Segura, supra note 210.

213. Id.

214. Id.

215. Id.

216. Id. 
harrowing." ${ }^{217}$ In Dr. Edgar's professional opinion, the autopsies demonstrated that the inmates "felt the panic and terror of asphyxiation before they died." 18 Midazolam was clearly not working as a proper anesthetic, just as anesthesiologists had warned. Additionally, the second and third drug in the cocktail Ohio was using, if injected without a proper anesthetic, felt like "being buried alive while feeling fire in one's veins." 219

Other legal alternative methods to lethal injection in some states include the use of firing squads, hanging, electrocution, and nitrogen hypoxia. In Mississippi and Oklahoma, nitrogen hypoxia is allowed if lethal injection is held as unconstitutional or is otherwise unavailable. ${ }^{220}$ Electrocution is authorized if neither of those are available and, finally, firing squads can be used in some circumstances. $^{221}$ Utah authorizes firing squads if lethal injection drugs are unavailable or lethal injection is found to be unconstitutional. ${ }^{222}$ In New Hampshire, hanging is allowed if it is "impractical to carry out" executions by lethal injection. ${ }^{223}$ In Washington, an inmate may request hanging over lethal injection. ${ }^{224}$ In Alabama, the inmate may choose nitrogen hypoxia or electrocution instead of lethal injection. ${ }^{225}$ Electrocution is also legal in Arkansas, Florida, Kentucky, South Carolina, Tennessee, and Virginia as a choice for the prisoner. ${ }^{226}$

\section{INDIANA MOVING FORWARD}

\section{A. It is Cruel and Unusual Punishment to Leave an Inmate on Death Row Indefinitely}

Multiple U.S. Supreme Court justices have considered the lengthy execution delays cruel and unusual punishment. Justice Stevens wrote it was his belief that excessive delays from sentencing to executions can themselves be considered cruel and unusual punishment. ${ }^{227}$

As stated previously, the Supreme Court uses four principles to determine whether a punishment is considered "cruel and unusual" ${ }^{228}$ : (1) if the punishment,

217. Id

218. Id.

219. Id

220. Authorized Methods by State, DeAth Penalty Info. CTR., https://deathpenaltyinfo. org/executions/methods-of-execution/authorized-methods-by-state (last visited Feb. 27, 2021) [https://perma.cc/LAJ2-GX36].

221. Id.

222. Id

223. Id.

224. Id.

225. Id.

226. Id.

227. Gomez v. Fierro, 519 U.S. 918, 918 (1996) (Stevens, J., dissenting).

228. Furman v. Georgia, 408 U.S. 238, 282 (1972) (Douglas, J., concurring); see supra Section I.A. 
by its severity, is degrading to human dignity; (2) if the punishment is inflicted in an arbitrary fashion; (3) if the punishment is clearly and completely rejected in society; and (4) if the punishment is entirely unnecessary. ${ }^{229}$ Leaving an inmate indefinitely on death row with an irreversible execution looming overhead is cruel and unusual punishment. It is both degrading to human dignity and inflicted in an arbitrary fashion.

The Supreme Court has found the prolonged periods of isolation and confinement for death row prisoners create a significant "risk of serious psychological and emotional harm .... [P]rolonged solitary is linked to paranoia, hallucinations, depression, sleep disturbance, suicidal fixation, anxiety, irritability, rage and depression. ${ }^{, 230}$ Legal experts in the United States and other countries have concluded that the prolonged isolation is comparable to torture and is a form of cruel and unusual punishment. ${ }^{231}$ Inmates characteristically experience a decline in their mental health because of it. ${ }^{232}$ Further, both their physical and dental health decline, and some inmates in Indiana opt to have all of their teeth extracted instead of suffering any longer. ${ }^{233}$ All of this has a dehumanizing effect, and is degrading to human dignity, which is only aggravated by the uncertainty of whether the sentence will be carried out. ${ }^{234}$

Moreover, under the "objectively intolerable risk" test the Supreme Court established in Baze v. Rees, the lingering and indefinite death sentences being inflicted upon the death row inmates in Indiana constitute a substantial or objectively intolerable risk of serious harm, both mental and physical, and are therefore cruel and unusual punishment. ${ }^{235}$ Many inmates on death row have declared they would prefer to die rather than pursue their exoneration while living in these intolerable conditions. ${ }^{236}$

Furthermore, certain death row confinement conditions have been declared as cruel and unusual punishment, such as in Virginia. ${ }^{237}$ Death row solitary confinement conditions differ greatly from solitary confinement of regular inmates. Inmates on death row are held in solitary confinement for extensively long hours, usually twenty-three hours a day, in a cell smaller than a parking space, with their recreational time, time outside, and time to shower being significantly limited to only a few hours a week. ${ }^{238}$ Also, death row inmates, including those in Indiana, are often not allowed to interact with other people. ${ }^{239}$

229. Furman, 408 U.S. at 271-81.

230. Weiss, supra note 110.

231. Conditions on Death Row, Death Penalty Info. Ctr., https://deathpenaltyinfo. org/death-row/conditions-on-death-row (last visited Feb. 27, 2021) [https://perma.cc/ 753G-6JAM].

232. Id.

233. Death Row Conditions by State, Indiana, supra note 113.

234. Glossip v. Gross, 576 U.S. 863, 926 (2015) (Breyer, J., dissenting).

235. See id.

236. Id. at 928 .

237. Weiss, supra note 110.

238. Id.

239. Death Row Conditions by State, Indiana, supra note 113. 
Indiana is leaving the three men who have exhausted their appeals in these conditions open-endedly.

Joseph Corcoran, Benjamin Ritchie, and Roy Ward know their executions are final. They have exhausted their appeals, and there are no more chances to evade their death sentences. As Justice Miller said, a prisoner awaiting the execution of his death sentence is "one of the most horrible feelings to which he can be subjected," and "the uncertainty during the whole of it, ... as to the precise time when his execution shall take place," is worst of all. ${ }^{240}$ This statement, regarding a death row inmate in 1890, considered a period of four weeks to be disturbing. ${ }^{241}$ Corcoran, Ritchie, and Ward have been sitting on death row for twenty-two, nineteen, and eighteen years respectively. ${ }^{242}$ No one can determine how long they will continue to sit on death row, even though they have no chances or hope left — essentially just as dead men walking-making this truly the worst experience of all.

Further, the indefinite death sentences are cruel and unusual because they are being applied in an arbitrary manner. The U.S. Supreme Court decided in 1972 that the death penalty, as it was being administered, was unconstitutional. ${ }^{243}$ Out of the justices deciding Furman v. Georgia, only two held that the death penalty was unconstitutional in all circumstances. ${ }^{244}$ In concurring opinions, the rest of the majority had a variety of reasons for finding the death penalty to be unconstitutional, specifically the arbitrary nature of when it was imposed. ${ }^{245}$ The Court particularly stated the Cruel and Unusual Punishment Clause's primary function was to protect against the danger of arbitrary infliction. ${ }^{246}$ If the infliction of a severe punishment, such as the death penalty, is " something different from that which is generally done' ...., there is a substantial likelihood that the State, contrary to the requirements of regularity and fairness embodied in the Clause, is inflicting the punishment arbitrarily."247

An infliction of a punishment that is arbitrary is one that is "existing or coming about seemingly at random." 248 Looking at the current situation in Indiana, the death sentences of the Indiana death row inmates are being implemented arbitrarily. Without the necessary lethal injection drugs, executions have been put on hold with no permanent or even tentative date or manner of execution in sight. ${ }^{249}$ The executions could be at a standstill for days, months,

240. In re Medley, 134 U.S. 160, 172 (1890).

241. Id. at 162 .

242. State of Indiana Offenders Sentenced to Death, supra note 11.

243. See Furman v. Georgia, 408 U.S. 238, 257-306 (1972) (Brennan, J., concurring); id. at 314-71 (Marshall, J., concurring).

244. Id. at 375 .

245. Id. at 276-77.

246. Id. at 277 (Douglas, J., concurring).

247. Id. at 276-77 (quoting Trop v. Dulles, 356 U.S. 86, 100 n.32 (1958)).

248. See Arbitrary, MERRIAM-WeBSTER, https://www.merriam-webster.com/dictionary/ arbitrary (last visited Jan. 11, 2020) [https://perma.cc/J9ZK-QTGD].

249. Bates, supra note 183. 
years or even decades until the drugs become obtainable or Indiana adopts a new policy. The executions are currently without a set schedule or method of executions, creating a random, indefinite, and open-ended system. Therefore, the indefinite death row sentences of inmates are arbitrary and thus unconstitutional.

\section{B. Indiana Should Abolish the Death Penalty and Impose Life Without Parole Sentences Instead}

Since the typical three-drug cocktail is no longer an option for executions, it is undisputed that a change must happen. Indiana has a few alternatives to consider.

There is the option of altering the three-drug cocktail to a different combination of drugs. This would involve receiving drugs from compounding pharmacies, but these are not heavily regulated, ${ }^{250}$ and the FDA does not validate the effectiveness or safety of the drugs that compounding pharmacies produce. ${ }^{251}$ Furthermore, utilizing a different combination of drugs to perform lethal injections has shown to be risky and sometimes ineffective: Lockett, ${ }^{252}$ McGuire, ${ }^{253}$ and Wood $^{254}$ are only three examples out of many where an experimental "blend" has not worked as planned. ${ }^{255}$ Thus, this would not be a suitable method.

There is the option of using only pentobarbital. However, the use of this single drug has not been entirely effective either. ${ }^{256}$ Additionally, drug manufacturers around the world are placing distribution controls on pentobarbital, which has resulted in a shortage. ${ }^{257}$ As revealed when the federal government resumed executing inmates with only pentobarbital in 2020, it is unclear how or where the federal government obtained pentobarbital, and states methods in obtaining pentobarbital have been cloaked in secrecy. ${ }^{258}$ With the secrecy and the beginning shortage, this may not even be a potential option for long. There have already been questions amongst the courts of whether the use of pentobarbital is an acceptable method, clearly making it an unfavorable choice for Indiana.

The central problem with all these drug changes and experimental mixtures is they have not been thoroughly tested and are almost completely unregulated and unapproved; thus, there is relatively little research as to whether these drugs show efficacy and painlessness. ${ }^{259}$ With the multitude of shortages surrounding nearly all of the drugs utilized for lethal injections, states began concocting their

250. Id

251. Booth, supra note 15 , at 418 .

252. Bates, supra note 183.

253. Ford, supra note 26.

254. Serwer, supra note 182.

255. See supra Section IV.B.

256. Ford, supra note 26.

257. Booth, supra note 15, at 402.

258. Brownlee, supra note 60; Neilson, supra note 44.

259. Neilson, supra note 44. 
own cocktail mixtures, resulting in the excruciating executions previously mentioned. ${ }^{260}$ Without knowledge of if these drugs being administered are effective or painless, neither the drug mixtures nor single-drug use are appropriate methods of executions.

Another option would be to reinstate old methods of execution, including firing squad, hanging, nitrogen hypoxia, and the electric chair. Although still a legal alternative to lethal injection in some states, these barbaric means of execution present the potential of being considered cruel and unusual punishment. For example, the Nebraska Supreme Court declared in 2008 that the electric chair was cruel and unusual punishment because it "inflict(ed) intense pain and agonizing suffering." ${ }^{261}$ Nebraska was the only state that actually utilized the electric chair as their sole form of execution until this decision. ${ }^{262}$

Finally, there is the option of abolishing the death penalty in Indiana completely and imposing life sentences without parole in its place. Capital punishment has rapidly been falling out of favor nationally, and many states have begun abolishing it or placing moratoriums on it. ${ }^{263}$ Today, twenty-three states and the District of Columbia have abolished the death penalty. ${ }^{264}$ Three have placed a gubernatorial moratorium on it. ${ }^{265}$

Indiana has not executed a death row inmate since 2009, and those in favor of capital punishment nationwide are declining. ${ }^{266}$ When the U.S. Supreme Court decided Furman v. Georgia in 1972, the seven men on Indiana's death row at the time had their sentences reduced to life in prison. ${ }^{267}$ Following this decision, the Indiana General Assembly enacted a statute regarding death penalty sentencing in an effort to replace the previously struck down statute. ${ }^{268}$ However, in 1977, the Indiana Supreme Court again struck down this newly enacted death penalty statute, and the eight men on death row had their sentences set aside and reduced to life in prison. ${ }^{269}$

Indiana is no stranger to setting aside sentences of death row inmates and

260. See supra Section IV.B.

261. Adam Liptak, Nebraska Supreme Court Outlaws Electric Chair, N.Y. TimES (Feb. 8, 2008), https://www.nytimes.com/2008/02/08/us/08cnd-penalty.html [https://perma.cc/9HFYY99L].

262. Id.

263. Gretchen Frazee, How States Are Slowly Getting Rid of the Death Penalty, PBS NewsHour (Mar. 13, 2019, 6:42 PM), https://www.pbs.org/newshour/nation/how-states-areslowly-getting-rid-of-the-death-penalty [https://perma.cc/NQ2B-HXDT].

264. State by State, supra note 17 (Alaska, Colorado, Connecticut, Delaware, Hawaii, Illinois, Iowa, Maine, Maryland, Massachusetts, Michigan, Minnesota, New Hampshire, New Jersey, New Mexico, New York, North Dakota, Rhode Island, Vermont, Virginia, Washington, West Virginia, and Wisconsin).

265. Id. (California, Oregon, and Pennsylvania).

266. State and Federal Info: Indiana, supra note 79.

267. Death Penalty Facts, supra note 64.

268. Id.

269. Id. 
granting life in prison instead when the death penalty, as being administered at that time, is found to be cruel and unusual. Leaving inmates indefinitely on death row after they have exhausted their appeals as Indiana is currently doing is cruel and unusual punishment. Therefore, Indiana should follow its own steps in history and set aside the current death sentences, granting in its place life in prison without parole to the inmates currently on death row.

\section{CONCLUSION}

The traditional three-drug cocktail for lethal injections is extinct. Pharmaceutical companies have made it impossible to obtain the necessary drugs. ${ }^{270}$ Because of this, Joseph Corcoran, Benjamin Ritchie, and Roy Ward, who have exhausted their possibilities to evade death, sit in their smaller-than-aparking-spot cells with no human contact, awaiting the minute they take their last breath. That could be at any time, or at no time at all - they have no idea.

Having inmates who have exhausted all their appeals wait indefinitely for their execution with death constantly looming overhead is cruel and unusual punishment. These lengthy delays subject death row inmates to decades of especially severe, dehumanizing conditions of confinement that are degrading to human dignity, and they undermine the rationale of even having the death penalty. ${ }^{271}$ The inability to set firm dates for executions creates an arbitrary system that leaves inmates with extreme uncertainty if their death sentence will even be carried out.

On top of this, many state courts have already determined that numerous death row confinement conditions are considered cruel and unusual, and the conditions these inmates are held in "threaten their health, safety, and human dignity" daily. ${ }^{272}$ Death row confinement conditions and prolonged isolation have been associated with "paranoia, hallucinations, depression, sleep disturbance, suicidal fixation, anxiety, irritability, rage and depression." 273 To subject inmates to these conditions indeterminately, in addition to a death sentence hanging overhead, is indeed cruel and unusual.

Indiana is now forced to alter its method of capital punishment or dispose of it completely. The options are altering the cocktail mixture, using one singular drug, re-instating old methods of execution, or abolishing the death penalty and replacing it with life imprisonment with no possibility of parole. "The rationale for capital punishment . . . classically rests upon society's need to secure deterrence, incapacitation, retribution, or rehabilitation." 274 Capital punishment is successful at incapacitating the offender, but life in prison without the

270. Booth, supra note 15 , at 395.

271. Glossip v. Gross, 576 U.S. 863, 925 (2015) (Breyer, J., dissenting).

272. ACLU National Prison Project, ACLU, https://www.aclu.org/other/aclu-national-prisonproject (last visited Feb. 27, 2020) [https://perma.cc/S39B-V2ZH].

273. Weiss, supra note 110.

274. Glossip, 576 U.S. at 929 (Breyer, J., dissenting). 
possibility of parole can also accomplish this successfully. ${ }^{275}$

The U.S. Supreme Court has said if the death penalty is not fulfilling its goals of deterrence or retribution, "it 'is nothing more than the purposeless and needless imposition of pain and suffering,' and hence an unconstitutional punishment."276 Today, very few executions are actually carried out, and those who are executed wait close to two decades on death row, sometimes longer. ${ }^{277}$ Statistically, an offender sentenced to death is more likely to have his sentenced overturned or commuted or to die of natural causes because of the delay than to be executed. ${ }^{278}$ Knowing how rare executions actually are, and the length of delay and litigation, it seems unlikely that the death penalty would have any significant deterrent effect on criminals. ${ }^{279}$

As for retribution, there is a strong argument that surviving relatives, friends, and communities would feel vindicated after an execution, but it is also likely that they would feel pain and suffering throughout the lengthy delay and appeals process ${ }^{280}$ Furthermore, people change, forgive, and find repentance, forgiveness, and acceptance. Even without an execution, the survivors could potentially receive their retribution knowing the offender will stay in prison forever.

When our Founding Fathers wrote the Constitution, executions took place extremely quickly after sentencing. ${ }^{281}$ In 1890 , the Supreme Court held that a four-week delay between sentencing and execution violated the Constitution. ${ }^{282}$ The average delay today is over twenty years. ${ }^{283}$ The lengthy delays now rampant in capital punishment cases "undermine[] any effort to justify the death penalty in terms of its prevalence when the Founders wrote the Eighth Amendment." 284

Public support for the death penalty is the lowest it has been in half a century, with only fifty-five percent of respondents surveyed in the Gallup Poll being in favor of the death penalty for a person convicted of murder. ${ }^{285}$ Forty-three percent responded they were completely opposed to the death penalty. ${ }^{286}$ In 2019 , for the first time since 1985, the majority of public opinion stated life imprisonment is a better approach to punishing crimes than the death penalty. ${ }^{287}$ Sixty percent of

275. Ring v. Arizona, 536 U.S. 584, 615 (2002) (Breyer, J., concurring).

276. Enmund v. Florida, 458 U.S. 782, 798 (1982) (quoting Coker v. Georgia, 433 U.S. 584, 592 (1977)).

277. Glossip, 576 U.S. at 930 (Breyer, J., dissenting).

278. $I d$.

279. Id. at 931.

280. Id. at 932 .

281. Id. at 933.

282. In re Medley, 134 U.S. 160, 175 (1890).

283. Time on Death Row, supra note 108.

284. Glossip, 576 U.S. at 933.

285. Gallup Poll: Public Support for the Death Penalty Lowest in a Half-Century, DEATH PENAlty INFO. CTR. (Nov. 24, 2020), https://deathpenaltyinfo.org/news/gallup-poll-public-supportfor-the-death-penalty-lowest-in-a-half-century [https://perma.cc/R7NW-UZ6S].

286. Id.

287. Gallup Poll - For First Time, Majority of Americans Prefer Life Sentence to Capital 
the public surveyed in 2019 chose life without possibility of parole, versus thirtysix percent who favored the death penalty. ${ }^{288}$ An increase in preference for life in prison was evident amongst Democrats, Republicans, and Independents alike. ${ }^{289}$ Twenty-three states have abolished capital punishment entirely and another three states have moratoriums in place. ${ }^{290}$ The least new death sentences were imposed in the United States in 2020 than any other year since the Supreme Court struck down all death penalty statutes in $1972 .{ }^{291}$ According to the Death Penalty Information Center's Year End Report for 2019, eleven states that still have the death penalty have not executed someone in a decade, including Indiana. ${ }^{292}$ For all of these reasons, Indiana should be next to abolish the death penalty and grant life without parole sentences in its place.

Punishment, DeAth Penalty Info. CTR. (Nov. 25, 2019), https://deathpenaltyinfo.org/news/gallup-poll-for-first-time-majority-of-americans-prefer-lifesentence-to-capital-punishment [https://perma.cc/6CSM-G5J5].

288. Id.

289. Id.

290. State by State, supra note 17.

291. The Death Penalty in 2020: Year End Report, Death Penalty Info. Ctr. (Dec. 16, 2020), https://deathpenaltyinfo.org/facts-and-research/dpic-reports/dpic-year-end-reports/the-deathpenalty-in-2020-year-end-report\#execution-and-sentencing-trends [https://perma.cc/4SGS-NR62].

292. Id. 